\title{
Indicator of change management: learning organization and strengthening process
}

\author{
Nurul Sahadila Abd Rani ${ }^{1}$, Mohd Izham Mohd Hamzah ${ }^{2}$ \\ ${ }^{1}$ Faculty of Education, Universiti Kebangsaan Malaysia \\ ${ }^{2}$ Education Policy \& Leadership Department, Faculty of Education, \\ Universiti Kebangsaan Malaysia
}

Correspondence: Mohd Izham Mohd Hamzah (email: izham@ukm.edu.my)

Received: 12 February 2020; Accepted: 16 April 2020; Published: 30 May 2020

\begin{abstract}
The mission of the Ministry of Education Malaysia is to create a world-class quality education system and to develop individual potential. This study aimed to identify the level of change indicators in the District Education Office (PPDs) and also to explore the implementation of the change indicators in strengthening PPDs. The study was conducted using the Explanatory Sequential Design approach, involving 93 Heads of PPDs who were selected using group sampling techniques and strata random sampling. Data was analyzed through SPSS. Then, a qualitative study was conducted, involving 13 Officers at PPDs who were purposively chosen through snowball sampling. Data was gathered through semistructured interviews and themes were developed and analyzed with NVivo 11 . The results show that the level of change indicators in the PPDs are at high; hence, qualitative findings show six themes of change indicators in PPDs, signifying that the indicators of change management in PPDs had been implemented well. The implications of this study provide added value and are used as a reference for PPDs to monitor and provide an early intervention if any issue was detected in the implementation of the change programme. Indepth studies are recommended to explore the factors that influence the success of change and practice of PPDs learning organization.
\end{abstract}

Keywords: change management, education, indicators of change, learning organization, Malaysia, strengthening

\section{Introduction}

The global technological revolution has changed the current learning by shifting more focus on virtual cyberspace environment with collaborative communication tools such as new formats in games, internet usage, and global community learning. Pelan Pembangunan Pendidikan Malaysia (PPPM) 2013-2025 aims to improve access, quality, equity, unity, and effectiveness of the delivery system to implement a better policy. The District Education Office (PPDs) has been empowered with decision-making, flexibility, and accountability in 
carrying out their duties that will enable effective planning for the school. Thus, The PPDs role is very important because the organization is closest to the school in terms of distance. The District Transformation Programme (DTP) aims to accelerate the improvement of school performance through a systematic programme led by the PPDs. The decentralization of power and authority, namely the decline and increase, enables the officials involved to carry out their duties more smoothly and confidently (Kementerian Pendidikan Malaysia, 2013). Thus, PPDs empowerment can help increase the efficiency and effectiveness of a programme that is intended to achieve educational aspirations.

The positive impact of the implementation of the District Transformation Programme has placed Malaysia in the middle position on the list of TIMSS (Trends in International Mathematics and Science Study) participating countries. In addition, Malaysia's achievement in the International Student Assessment Programme (PISA) 2015 increased significantly in three domains namely Scientific Literacy (443), Literacy Reading (431) and Math Literacy (446) (Kementerian Pendidikan Malaysia, 2016a). Malaysia's average score is only 50 points in the Organization for Economic Cooperation and Development (OECD). In TIMSS 2015, Malaysia showed the highest increase in science (44 points) among 16 countries, compared to that of TIMSS 2011 (Kementerian Pendidikan Malaysia, 2016b).

Kowal and Ableidinger (2011) stated that indicators are used by school leaders for notification and intervention purposes if the management is not on track. The indicator will act as a "red flag" that informs a need for direct intervention in the organization to ensure that it is in the right direction. Similarly, Mainguet and Baye (2006) stated that it is difficult to justify the success of a policy or programme without a change indicator. Thus, the established indicators will be the basis and the benchmarks to assist in the ranking and empowerment of PPDs as a learning organization and as a basis for continuous training.

In addition, to witness the process of strengthening PPDs and the changes that take place, the components of the DTP are based on the Buku Panduan Pengurusan Program Transformasi Daerah Edisi 3 (Kementerian Pendidikan Malaysia, 2017), which is used as the basis of this research. DTP consists of two main components - support and accountability. Support involves two main aspects: (i) empower local leadership; and (ii) provide support to most needed schools. Meanwhile, accountability concerns two components: (i) gain access, quality, and equity; and (ii) monitor discipline, problem solving, and action taking.

\section{Change indicators in District Education Office}

The DTP, based on the District Transformation Program Handbook 3.0 (Kementerian Pendidikan Malaysia, 2017), is also the basis of this study. DTP is made up of two main components: support (empowering local leadership and providing support to the schools most in need) and accountability. Components of local leadership are gearing toward changing the role of the PPDs, focusing more on efforts to increase support for schools in the district.

PPDs will support principals, teachers, and students through local and centralized solutions based on current data and information. Local solutions are planning and implementing interventions that meet the needs of schools to address a wide range of issues and challenges. The centralized solution is the planning and implementation of national interventions to address various national issues and challenges. In addition, the SIPartners+ program is established to provide guidance and support to the principal in improving the quality of leadership and organizational management, while the SISC+ teacher is responsible for guiding teachers toward improving the teaching and learning quality as well as helping to improve policy understanding, new curricula, and assessments for mentored teachers. 
The accountability component is meant to ensure access, quality, and equity through monitoring, problem-solving, and taking action. The MOE performance dashboard and PPDs excellence rating will focus on actionable interventions aimed at achieving the key performance indicator (KPI). The MOE performance dashboard displays a matrix of results based on access, quality, and equity, while matrix inputs are based on factors that influence the quality of teaching and learning. The MOE and PPDs excellence rating, performance dashboard serves as a tool for measuring, evaluating, and monitoring at national, state, district, and school levels to make sure that KPIs are achieved.

The components of discipline monitoring, problem-solving, and action-taking will use the performance dialogue (DP). DP is a forum implemented at all levels, from the MOE level to the school level, to discuss educational performance based on data and facts, followed by robust and focused actions to achieve KPI targets. In addition, DP is also a monitoring mechanism to ensure that DTP implementation is on the right track. The DP ensures that the data-driven decision-making cycle occurs at all levels.

Therefore, we will look at the following indicator components: a) the scope of the PPDs excellence rating work, b) the scope of the district program manager's duties, c) the roles and responsibilities of SIPartners+, d) the roles and responsibilities of SISC+, e) the provision of responsibilities, f) DP, g) KPIs, h) dashboards, and i) PPDs excellence rating. This study has two objectives. First, to determine the level of change indicators in the PPD. Second, to explore change indicators in the context of strengthening PPDs (Figure 1).

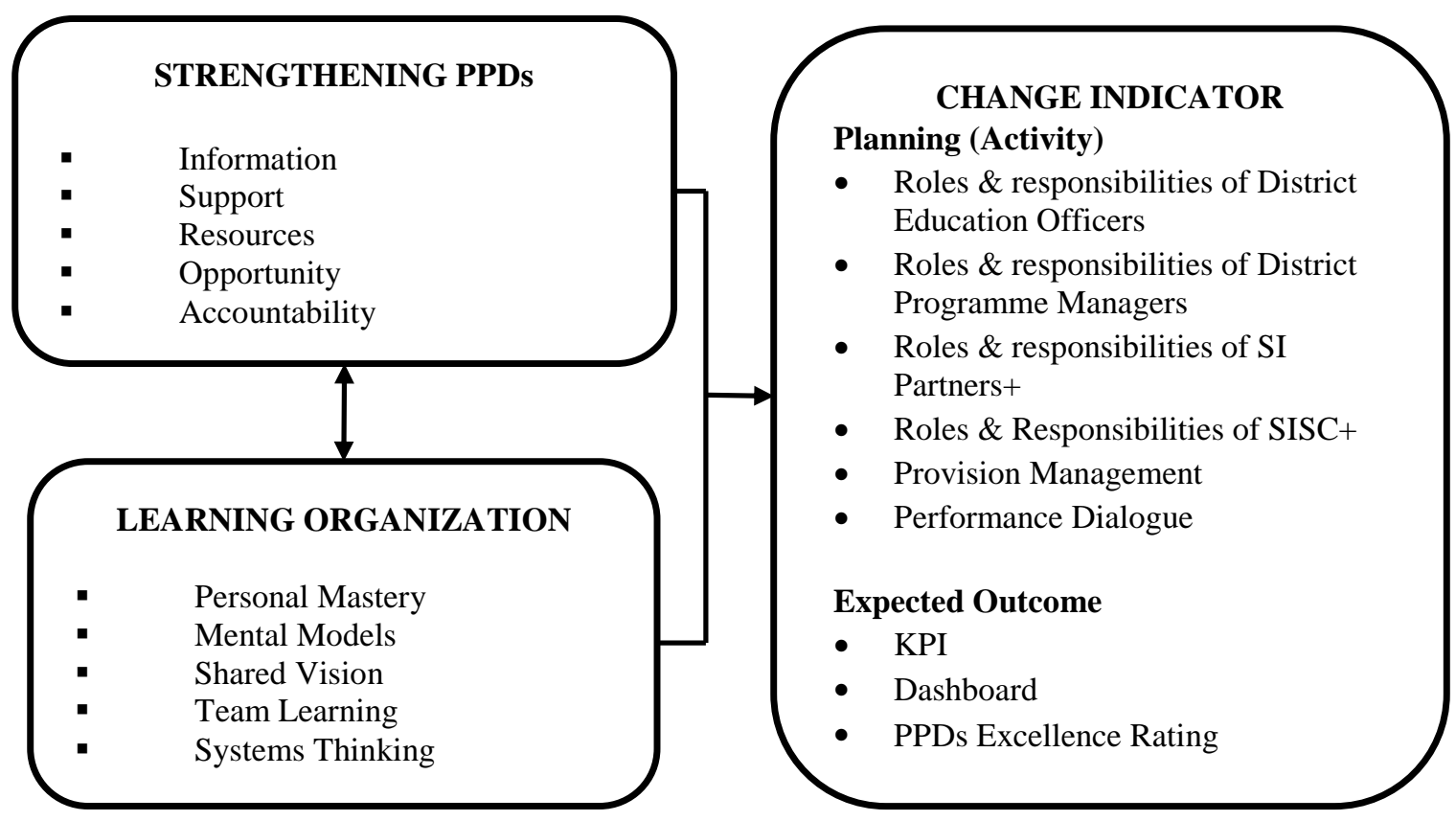

Figure 1. Conceptual Framework - Empowerment Structure Theory - Kanter (1993), Five Principles of Learning Organization - Senge (1990) and integration of Model Logic - Kellogg (2004) with District Transformation Programme (2017b) Component

\section{Methodology}

The study was conducted using the mixed method (Explanatory Sequential Design) approach with the survey design. This study uses questionnaire survey as an instrument. The questionnaire was adapted from the Questionnaire-I \& II (CWEQ) by Laschinger (2012), Park (2006), The Learning Organization Questionnaire for Schools, the Book of 
Transformation Programme 3.0 (DTP), and appropriate literature reviews. Three experts were involved in validating of the instrument in terms of face validity and content validity.

The researchers appointed a three-consultant panel to evaluate the validity of the questionnaire that has been set up. Idris (2013) states that the purpose of this validation process is to enhance the content, assess the suitability of the language, clarify the meaning of the items, and assess whether the items used are able to measure every construct that being studied. The panel was comprised of lecturers from other universities who have expertise and experience in the field of education administration, change management, and educational change. Overall, the panel accepted all the constructs with some modifications. Pilot studies were also conducted on 30 Heads of District Education Office (HDEOs) and the reliability value of Cronbach's Alpha was 0.792 . This value is considered good and satisfactory based on Pallant (2005) and Creswell (2012).

Next, 93 HDEOs were selected from five zones in Malaysia namely the northern zone, southern zone, eastern zone, central zone, and East Malaysia zone through group sampling technique and random sampling strata. Descriptive analysis was used to see the change indicators, while inference analyses, such as multiple correlation and regression were used to see the relationship and contribution to the variables studied. The Statistical Packages for Social Science (SPSS) version 2.2 was used for analysing the data.

Then, the qualitative study employed a Multiple Case Study research design to explore the change indicators and learning organization at PPDs. Data was collected through semi-structured interviews. Participants were purposively selected through purposive sampling and snowball sampling. Five PPDs, including two State Education Departments, were involved in this study. These participants were directly involved in the implementation of change in strengthening PPDs through the DTP. As a learning organization, the participants also have knowledge and experience in implementing change, including the SISC + and SI Partners + programmes. They are also capable of making reflections and giving clear explanations (Mohd Hamzah \& Azman, 2009).

In addition, the interview transcriptions were given to the participants as a means of member checking to ensure that the participants' responses were accurately transcribed and that the data were accurately interpreted, ensuring that the themes were correctly developed. The NVivo 11 application was used to manage the data according to themes and sub-themes according to the research questions and research framework seven (7) officers were involved, consisting of five District Education Officers and two Programme Managers (Table 1).

Idris (2013) recommended that researchers obtain Kappa values above 0.70 before they make further analysis. If the value is lower, the researcher needs to discuss with the expert about the definition of each construct used and the data chosen to illustrate the meaning of the construct. Thus, in this study, researchers have used Cohen Kappa Coefficient Index Analysis to determine the reliability of categories, themes, sub-themes, and other subthemes obtained from interview findings. The researchers have gained the views of three qualitative experts to evaluate the emerging themes prior to calculating the value of consensus of the appointed experts. The result of the calculations shows that the overall average value of the Kappa coefficient of approval is 0.822 , which is deemed very strong (Idris, 2013). Then, the NVivo 11 application was used to manage the data according to themes and sub-themes based on the research questions and framework. In terms of the level of interpretation the change management indicators refer to the interpretation scores presented by Tschannen and Gareis (2004) as in Table 2. 
Table 1. The informants for the semi-structured interviews

\begin{tabular}{|c|c|c|c|}
\hline Informant & Position & Service Period & State \\
\hline HDEO1 & $\begin{array}{l}\text { Head of District } \\
\text { Education Officer }\end{array}$ & Less than one year & Selangor \\
\hline HDEO2 & $\begin{array}{l}\text { Head of District } \\
\text { Education Officer }\end{array}$ & 2 years & Melaka \\
\hline HDEO3 & $\begin{array}{l}\text { Head of District } \\
\text { Education Officer }\end{array}$ & 5 years & Johor \\
\hline PM4 & Programme Manager & More than 11 years & Putrajaya \\
\hline HDEO5 & $\begin{array}{l}\text { Head of District } \\
\text { Education Officer }\end{array}$ & 2 years & Perak \\
\hline PM6 & Programme Manager & 3 years & Kedah \\
\hline HDEO7 & $\begin{array}{l}\text { Head of District } \\
\text { Education Officer }\end{array}$ & 2 years & Kelantan \\
\hline
\end{tabular}

Table 2. Mean score

\begin{tabular}{cl}
\hline Mean Score $(\mathbf{M})$ & \multicolumn{1}{c}{ Interpretation } \\
\hline $1.00-1.80$ & Very Low \\
$1.81-2.60$ & Low \\
$2.61-3.40$ & Medium \\
$3.41-4.20$ & High \\
$4.21-5.00$ & Very High \\
\hline
\end{tabular}

\section{Research Findings}

Table 3 shows the level of change management indicators in the context of empowering the PPDs. The result shows a high level of change management indicators in the context of empowering the PPDSs as a whole, with a mean score of 4.67. The components of the planning (activity) obtained the highest mean (mean $=4.68$ ), followed by the expected outcome (mean $=4.60)$. This shows that change management indicators have been implemented well in the PPDs.

The component of planning (activity) consists of indicators such as roles and responsibilities of the HDEOs, the roles and responsibilities of the Programme Managers, the roles and responsibilities of SI Partners +, the roles and responsibilities of SISC +, Performance Dialogue, and provision management. In detail, the analysis shows that the highest mean score is the roles and responsibility of SISC + (mean $=4.72)$, followed by Performance Dialog (mean $=4.71)$. Next, the third highest mean is the provision management $($ mean $=4.69)$, followed by the roles and responsibilities of SI Partners $+($ mean $=4.68)$. In addition, the roles and responsibilities of the HDEOs (mean =4.67). However, the lowest mean value is the roles and responsibilities of the Programme Managers (mean $=4.66$ ).

Next, the desired output component consists of indicators such as Key Performance Indicator (KPI), Dashboard, and Excellence Rating of the PPDs. In detail, the analysis shows that the highest mean score is the Excellence Rating of the PPDs (mean =4.67). In addition, the Dashboard (mean $=4.58$ ) has the majority of 68 people $(73.0 \%)$ who strongly agreed. However, the lowest mean value among the three indicators is the Key Performance Indicators (KPI) (mean $=4.58)$. 
Table 3. Level of level of change indicators in the PPDs

\begin{tabular}{lccc}
\hline \multicolumn{1}{c}{ Variables } & Mean & $\begin{array}{c}\text { Standard } \\
\text { Deviation (SD) }\end{array}$ & Interpretation \\
\hline Planning (Activity) & 4.67 & 0.32 & Very High \\
$\begin{array}{l}\text { Heads of District Education Office: Roles and } \\
\text { Responsibilities }\end{array}$ & 4.66 & 0.39 & Very High \\
Programme Managers: Roles and Responsibilities & 4.68 & 0.39 & Very High \\
SI P+ : Roles and Responsibilities & 4.72 & 0.38 & Very High \\
SISC+ : Roles and Responsibilities & 4.69 & 0.41 & Very High \\
Provision Management & 4.71 & 0.40 & Very High \\
Performance Dialogue & $\mathbf{4 . 6 8}$ & $\mathbf{0 . 3 3}$ & Very High \\
Planning Outcome Result & & & \\
Expected Outcome & 4.58 & 0.46 & Very High \\
Key Performance Indicators (KPI) & 4.58 & 0.45 & Very High \\
Dashboard & 4.67 & 0.47 & Very High \\
PPDs Excellence Rating & $\mathbf{4 . 6 0}$ & $\mathbf{0 . 4 2}$ & Very High \\
Expected Outcome Result & $\mathbf{4 . 6 7}$ & $\mathbf{0 . 3 4}$ & Very High \\
Change Indicators Result & &
\end{tabular}

Change Indicators in the Context of PPDs Strengthening Process (Planning Component)

The second objective is to explore what would be the change indicators in strengthening PPDs through the DTP. Findings illuminate nine themes, as follows:

a. HDEOs: Roles and Responsibility

The roles and responsibilities encompass four sub-categories: (i) empowering School Leadership; (ii) chairing the Performance Dialogue; (iii) implementing Instructional Guidance Model; and (iv) getting involved with External Bodies.

Apart from that, The HDEOs needs to implement the following Five Steps Instructional Guidance Model in the DTP such as (i) focusing on Specific Aspects of Teachers' Needs and Students' Performance; (ii) conducting Guidance Sessions; (iii) monitoring Action Plans; (iv) identifying Exact Issues and Data Analysis; and (v) ensuring School Implement Action.

Programme Manager 4 (PM4) said that there is a need to focus on specific aspects of teachers' needs and students' performance:

"So, the integrated schools visit involved all with all the heads of the sector;

we not only see the management of schools and academics but all aspects"

(PM4).

\section{b. Programme Manager: Roles and Responsibility}

For the Programme Manager's roles and responsibilities, the specific sub-categories are (i). to monitor, measure, and report Schools' Performance to PPDs; (ii) to manage Continuous Follow-ups and Improvements; (iii) to plan Support Programme and Intervention; and (iv) to attend Briefing on Roles.

In carrying the roles of a Programme Manager, the Assistant District Education Officer needs to monitor, measure, and report a school's performance as described by HDEO5. 
"Then, set the target and monitor the performance of the school was also seen as part of DTP's" (HDEO5).

c. SIP+ (School Improvement Partners): Roles and Responsibilities

SIP+'s roles and responsibilities are divided into the following sub-categories: (i). Guiding; (ii) Mentoring \& Coaching; (iii) Training; and (iv) Reporting.

SIP+'s roles and responsibilities in Guiding include (i) guidance toward Schools Achievement; (ii) guidance based on School Needs; (iii) guiding School Leaders; and (iv) conducting School Visits.

HDEO1 said that the roles and responsibilities of SIP+ is to provide coaching based on a school's achievement:

"SIP he will look at the same aspect with SISC as well. Five, six and seven (school band). If the education district does not have school with band six and seven (lowers school band). So, the SIP+ will go to the lowest band schools because we (SIP+) go to a low performing school in DTP" (HDEO1).

d. SISC+ (School Improvement Specialist Coaches): Roles and Responsibilities

Findings on the roles and responsibilities of SISC+ are divided into the following categories:

(i) Guiding (Mentoring and Coaching); (ii) Training; and (iii) Reporting.

The SISC+'s roles and responsibilities as a guide involve mentoring and coaching: (i) for schools' achievements; (ii) for schools' needs; (iii). pedagogy experts; (iii) for teaching and facilitating $21^{\text {st }}$ Century Education; and (iv) across all subjects.

HDEO2 admitted that guiding is one of their roles and responsibilities based on Schools' Achievement:

"As SIC+ also focus in mentoring schools that are band 5 and 6. We focus on this band" (HDEO2).

Change Indicators in the Context of PPDs Strengthening Process (Expected Outcome Component)

a. Performance Dialogue

Collectively, findings from the interviews indicate various perceptions related to the implementation of the Performance Dialogue conducted by PPDs. The sub-categories developed are (i) Problem Solving and Support; (ii) Review Performance Based on Data; (iii) Identify Problem; (iv) Focused Performance Dialogue; (v) Frequency of Performance Dialogue; and (vi) Summary for Action.

PM4 said that through performance dialogues, problem solving and support are given:

"So, every month we make a performance dialogue, we will discuss the problems faced and we will guide them" (PM4).

b. Provision Management

Findings indicate various perceptions related to the management of provision in implementing DTP. The themes are (i) Five Steps Intervention Plan (Plan Intervensi Lima 
Langkah @PILL); (ii) Provision from Education Performance and Delivery Unit PADU (Unit Pelaksanaan \& Prestasi Pendidikan); and (iii) Financial Assistance from External Bodies.

In managing Provision for DTP, PPDs seek aids from external bodies such as from members of parliament:

"Member of Parliament here support us in PPDs... we have good support from him. In DTP 3.0 we want to achieve the $21^{\text {st }}$ Century Education, so he (member of parliament) supports us in terms of contributing LCD projector" (HDEO7).

c. Key Performance Indicators (KPI)

Finding from the data of interviews in relation to Key Performance Indicator are categorized into six aspects. They are (i) Setting of District Education Office KPI; (ii) Urban and Rural Gap; (iii) KPI of Students' Attendance; (iv) Academic Performance in Public Exam; (v) Improving School Band; and (vi) Monitoring KPI.

Finding from the interview with PM4 found that there is also a need for PPDs to have its own KPI:

\begin{abstract}
"KPIs came from Ministry of Education to us (PPDs) then to school. But since 2018 I have to look at the data of schools how many percent of the school can achieve the KPI...there has a trend and it depend on how much we want to achieve. So, every school has their own KPIs, we made a preliminary discussion for that particular year...on average, how many KPIs the school can achieve. Our school KPI will be available in State Education Department/ PPDs Putrajaya. Now the KPI is from bottom (schools)" (PM4).
\end{abstract}

d. Dashboard

Findings related to Dashboard include 3 categories such as (i) Display of Main Performance Indicator; (ii) Guide for PPDs to Monitor Schools in a District; and (iii) Data from Various Sources.

PM6 in the interview said the following regarding Assessment Result of Public and School Examination:

"We refer (big data) to the exam is mid-year, SPM and so on" (PM6).

\title{
e. PPDs Excellence Rating
}

The Verification of the Star Rating by the State Education Department (JPN):

"Yes, it is verified by JPN itself, then BPSH (Bahagian Pengurusan Sekolah Harian or Daily School Management Division) will do the verification again, BPSH will go down to PPDs then the PPDs with 5 stars rating he will lead among the PPDs in the state" (HDEO3).

\section{Discussion}

The level of organizational learning practice at PPDs is at a very high level. In detail, the HDEOs practices a personal mastery, followed by a shared vision, team learning, thinking system, and mental model. This shows that the HDEOs has practiced the five principles of 
learning organization well in managing change in PPDs. This is consistent with the findings from a study by Ghani et al. (2014) that the level of organizational learning practice in an excellent school is at a high level where the individual learning aspect is highly practiced compared to the organizational leadership aspect, due to the school's being categorized as an excellent school.

Then, in strengthening the PPDs, the HDEOs needs to empower school leadership by providing support to the school through instructional guidance, which consists of four aspects: focusing on school achievement; helping the school recognize data-based strategic issues; guiding school leaders in daily management; and monitoring the implementation or action at school level. According to Veelen et al. (2017), school leaders are highly autonomous and, thus, are expected to be capable of developing their own system of quality assurance through reliable and valid self-evaluation, and to provide information on performance indicators, such as student achievement, parent satisfaction, and teacher professionalism. In addition, in carrying out the roles of programme manager, access to information is important in planning tasks; either to monitor, guide, or take action to ensure that the intervention taken will give a positive impact on the school's achievement. This is also in line with Thuss et al. (2016) study, where information is important in the process of empowering the learning environment in healthcare practices.

Furthermore, the roles and responsibilities of SIP+ are to guide in making plans based on data. SI Partners+ should implement guidance to principals and teachers hrough coaching and mentoring on three aspects, such as school achievement, guidance for data-based school improvement, as well as school administrator leadership. This finding is in line with the findings of Rani et al. (2018) that training and development are able to create positive influence among the staff. Meanwhile, the roles and responsibilities of the School Improvement Specialist Coaches (SISC +) comprise three main roles: giving guidance to teachers in PdPc (Coaching \& Mentoring), training, and making weekly reporting. SISC+ is to guide teachers at schools with low band. Said et al. (2016) also noted that the focus of the SISC+ programme is subject to the Standard Operating Procedures (SOPs) set by the MOE, which is the prioritized in low-performing schools (Bands 4, 5, 6, and 7).

Also, Performance Dialogue is significant in DTP to make PPDs an organization where learning and discussion play a role in ensuring their capability to identify any issue or problem to be handled effectively. This is supported by Ghani et al. (2014) study, that an organization's structure and system need to support the staff to form a working team that can solve issues as a team, and this team's work spirit needs to cut across all fields or departments. Apart from that, in managing the provision, PPDs need to make a programme planning and seek provision based on PILL (Five Step Intervention Plan) intervention that has been approved. During the implementation of the PILL, the Head of the PPDs will discuss with the officers involved to identify the best issues and interventions that can be implemented. This finding is consistent with the findings of Mohd Arus et al. (2018), which showed that the Headmaster provides space for his subordinates and teachers to give insights and ideas on the distribution of per capita grant aid (PCG) of the subject in the meeting prior to making a joint decision.

In general, in terms of the practices of a learning organization, the main theme identified was team learning, where information sharing was evident in all PPDs involved since they frequently have discussions, such as the Performance Dialogue, morning briefings, meetings, and other discussions. Information sharing also takes place when any member of the organization receives new knowledge about DTP. The findings of this study support the study findings by Keong et al. (2018), indicating that school teachers share information feedback or other information, especially on the improvement of learning and teaching activities related to student achievement. This sharing of information further provides new 
knowledge to all staff that can be used in performing their tasks. Maidin (2013) affirmed that team learning is a process of sharing and data collecting from colleagues with various experience, expertise, and ideas. It is also evident that leaders encourage staff to attend courses, while staff display initiatives to attend those courses. Doing so will help staff increase their knowledge and skill in carrying out their tasks. This finding is in line with Ishak et al. (2014) study on leadership practices at high performance schools, highlighting that attending courses is significant in increasing one's knowledge and skill.

Findings from the interviews also indicate shared visions, evident in discussions between leaders and staff. HDEOs admitted that they frequently share visions with the staff, particularly on matters related to DTP. This sharing of visions can increase commitment and teamwork spirit of an organization (Ong, 2012). This is also in line with Senge (1990) claim that shared visions can motivate staff to contribute to the success of an organization. Thus, in implementing changes in PPDs, the KPDDs build mutual trust with staff through friendly relationships, where they know the weaknesses and strengths of staff and have a good relationship with the school. The findings of this study support the findings of the study by Yaakob et al. (2017), which showed that collaboration practices can foster the sense of belonging among teachers in the school.

\section{Implication}

The implication of the DTP (District Transformation Programme) is an indicator that can measure and determine the extent of changes that take place towards success. This is because an indicator is a guide that describes an existing or current situation. The implication for the State Education Department (JPN) and District Education Office (PPD) is that the change indicator will have a positive impact, particularly for implementing changes in programmes. The indicator is also an early intervention to identify any issue or problem throughout the change implementation process. Hence, through the change indicator, the DTP's progress and performance can be assessed according to the mission and goals set. In addition, under the Sixth Shift of the 2013-2025 Malaysian Education Plan, the implication is that the indicator will assist policy makers and PPD staff in monitoring the DTP to be on the right track. Positive of negative change will be detected in the running of the programme, and thus immediate intervention can be taken. This study is also significant to policy makers at the MOE, particularly at the Aminuddin Baki Institution (IAB), for them to plan relevant training and courses for all educators. Ultimately, this study is significant to Principals or Headmasters and teachers, for the guidance and support they would receive from the SI Partners+ and SISC+ to increase their schools' performance, apart from being a means of early intervention for detecting issues or problems in the transformational programme.

\section{Conclusion}

In conclusion, there is a need for change management indicators in order to strengthen PPDs to ensure that the aims of DTP are achieved. Results show the relevant change indicators are essential: the roles and responsibilities of HDEOs, Programme Managers, SIP+, and SISC+; Performance Dialogue; Provision Management; Key Performance Indicators (KPI); Dashboard; and PPDs Excellence Rating. The absence of any indicator would hinder the monitoring of changes. It will also raise issues related to benchmarking changes in the DTP. Subsequently, the change indicators in DTP will be the 'red flags' to indicate whether or not the change implementation is on the right track. In-depth studies are recommended to explore 
the factors that influence the success of change and practice in PPDs as learning organizations.

\section{Acknowledgement}

The researchers would like to acknowledge the Ministry of Higher Education (MoHE) for the financial funding of this research through the Fundamental Research Grant Scheme (FRGS) [Code: FRGS/1/2016/SSI09/UKM/02/9] \& Research Grant FPEND 1 (GG-2019-031).

\section{References}

Creswell, J. (2012). Educational research: Planning, conducting and evaluating quantitative and qualitative research. (4th edition). Boston, United States of America: Pearson.

Ghani, M. F. A, Ishak, R., Siraj, S., \& Kenayathulla, H. B. (2014). Keberkesanan amalan organisasi pembelajaran di sebuah sekolah cemerlang di Kuala Terengganu, Terengganu: Satu kajian awal. Jurnal Kurikulum dan Pengajaran Asia Pasifik, 2(3), 22-42. (In Malay)

Idris, N. (2003). Penyelidikan dalam pendidikan. (Edisi Kedua). Selangor, Malaysia: McGraw Hill Education. (In Malay)

Ishak, R., Ghani, M. F. A. \& Siraj, S. (2014). Amalan kepimpinan organisasi pembelajaran di sekolah berprestasi tinggi Malaysia. Jurnal Kepimpinan Pendidikan, 1(2), 1-12. (In Malay)

Kanter, R. M. (1993). Men and women of the corporation. ( $2^{\text {nd }}$ Ed.). New York: Basic Books.

Kellogg, W. K. (2004). WK Kellogg Foundation Logic Model Development Guide. Michigan: WK Kellogg Foundation.

Kementerian Pendidikan Malaysia. (2013). Pelan Pembangunan Pendidikan Malaysia 20132025. Putrajaya, Malaysia: Kementerian Pendidikan Malaysia. (In Malay)

Kementerian Pendidikan Malaysia. (2016a). PISA 2015. Putrajaya, Malaysia: Kementerian Pendidikan Malaysia. (In Malay)

Kementerian Pendidikan Malaysia. (2016b). Laporan TIMSS 2015. Putrajaya, Malaysia: Kementerian Pendidikan Malaysia. (In Malay)

Kementerian Pendidikan Malaysia. (2017). Panduan Pengurusan Program Transformasi Daerah. (Edisi 3). Putrajaya, Malaysia: Bahagian Pengurusan Sekolah Harian. (in

Malay)

Keong, C. C., Ghani, M. F. A., \& Abdullah, Z. (2018). Cabaran amalan komuniti pembelajaran dalam kalangan guru Sekolah Rendah Berprestasi Tinggi Malaysia.

Jurnal Kurikulum \& Pengajaran Asia Pasifik, 6(3), 1-14. (In Malay)

Kowal, J., \& J. Ableidinger. (2011). Leading indicators of school turnarounds: How to know when dramatic change is on track. Charlottesville, VA: University of Virginia. Retrieved from https://files.eric.ed.gov/fulltext/ED539555.pdf.

Laschinger, H. (2012). Conditions for work effectiveness questionnaire I and II: User manual. Retrieved from CWEQ I \& II user manual. pdf.

Maidin, N. F. (2013). Amalan organisasi pembelajaran di sekolah cemerlang: Satu kajian kes. Doctoral dissertation, Universiti Kebangsaan Malaysia. (In Malay)

Mainguet, C., \& Baye, A. (2006). Defining a framework of indicators to measure the social outcomes of learning. Proceedings of the Copenhagen Symposium, 153-163. 
Mohd Arus, I. K., Samsuddin, S., Zawawi, N. H., \& Ab Ghani, M. F. (2018). Kepimpinan guru besar dan keberkesanan pengurusan kewangan peruntukan geran per kapita sekolah rendah zon Bangsar. Jurnal Kepimpinan Pendidikan, 5(2), 26-44. (In Malay)

Mohd Hamzah, M. I. \& Azman, N. (2009). Pandangan pentadbir terhadap implementasi proses perubahan terancang pada sekolah bestari di Malaysia. SosioHumanika, 2(1), 75-88. (In Malay)

Ong Gua Pak. (2012). Organisasi pembelajaran. Jurnal Pengurusan Awam, 1(9), 103-117. (In Malay)

Pallant, J. (2005). SPSS survival manual second-edition: A step by step guide to data analysis using SPSS. Sydney: Allen \& Unwin.

Park, J. H. (2006). Measurement and validation of Senge's learning organization model in Korean vocational high schools. Doctoral dissertation, University of Georgia.

Rani, N. A., Sulaiman, W. I. W., \& Mahbob, M. H. (2018). Pengaruh budaya organisasi terhadap latihan dan pembangunan dalam kalangan kakitangan kumpulan sokongan di UPM. 2016. e-Bangi Journal of Social Sciences and Humanities, 11(2), 142-173. (In Malay).

Said, R. R., Brahim, M., \& Md Sabil, A. (2016). Bimbingan dan pementoran berfokus olehSISC+ BM: Impak terhadap kualiti pengajaran guru Bahasa Melayu di sekolahsekolah menengah daerah Samarahan, Sarawak. Jurnal Pendidikan Malaysia, 41(2), 131-139. (In Malay)

Senge, P.M. (1990). The fifth discipline: The art and science of the learning organization. New York: Doubleday Dell Publishing Group.

Senge, P. M. (1992). The fifth discipline field book: Strategies and tools for building learning organization. New York: Doubleday Dell Publishing Group.

Thuss, M., Babenko-Mould, Y., Andrusyszyn, M. A., \& Laschinger, H. K. (2016). Nursing clinical instructor experiences of empowerment in Rwanda: Applying Kanter's and Spreitzer's theories. International Journal of Nursing Education Scholarship, 13(1), 117-125.

Tschannen-Moran, M. \& Gareis, C. R. (2004). Principle's sense of efficacy: Assessing a promising construct. Journal of Educational Administration, 42(5), 573-585.

Veelen, R. V., Sleegers, P. J., \& Endedijk, M. D. (2017). Professional learning among school leaders in secondary education: The impact of personal and work context factors. Educational Administration Quarterly, 53(3), 365-408.

Yaakob, M. F. M., Ramle, M. R., \& Yunus, J. (2017). Konsep kolaborasi dalam komuniti pembelajaran profesional: Satu tinjauan dari perspektif Islam. Geografia-Malaysian Journal of Society and Space, 12(10), 1-9. (In Malay) 